\section{Tomato Ringspot Virus Reduces Dandelion Top Weight and Flower Production under Field Conditions}

\section{C.A. Powell}

Institute for Food and Agricultural Sciences, Agricultural Research and

Education Center, University of Florida, Fort Pierce, FL 34954

W.L. Mountain and M.A. Derr

Bureau of Plant Industry, Pennsylvania Department of Agriculture, Harrisburg, PA 17110

Additional index words Taraxicum officionale, disease transmission, prunus stem pitting
Tomato ringspot virus (TmRSV) infection is associated with disease in many fruit crops. In Pennsylvania and surrounding states, the most economically important TmRSV-induced disease is prunus stem pitting (PSP) of peach [Prunus persica (L.) Batsch.]. Common dandelion (Taraxicum officionale Weber) is of potential epidemiological imweed is widely distributed throughout the northern United States, has a high population density in many orchards, and is frequently infected with TmRSV (Powell et al., 1984a, 1984b). Infected dandelions serve as donor plants for TmRSV transmission by Xiphinema rivesi, the dagger nematode, and can transmit TmRSV to progeny via seed (Mountain et al., 1983). We investigated the effect of TmRSV on common dandelion survivability, flower production, and fresh weight under field conditions to better assess its role in the PSP disease.

In April, a $20 \times 20 \mathrm{~m}$ field plot was plowed, disked, and fumigated with MC-2 (98\% methylbromide, $2 \%$ chloropicrin), which reduced the nematode populations to a nondetectable level when measured by wetsieving with Baermann funnel extraction. Two TmRSV-infected dandelion seedlings and two uninfected seedlings from each of four seed sources (derived from different orchards) were

Received for publication 28 Jan. 1991. Accepted for publication 27 Sept. 1991. Florida Agricultural Experiment Station Journal Series no. R-00713. The cost of publishing this paper was defrayed in part by the payment of page charges. Under postal regulations, this paper therefore must be hereby marked advertisement solely to indicate this fact. portance to the PSP disease. This perennial randomly transplanted into the fumigated plot within each of eight $9-\mathrm{m}^{2}$ blocks (16 plants per block). The dandelions were spaced in a $4 \times 4$ lattice; each dandelion was separated from its nearest neighbor by $60 \mathrm{~cm}$. The eight blocks were also randomized; four were mowed (as would be done in an orchard drive row) and four were not mowed.

At the end of 2 years, the number of flowers on surviving plants was counted; then the plants were harvested and the fresh weights of tops (above the crown-root junction) were determined. At the conclusion of the experiment, the surviving dandelions were assayed for TmRSV. Plants that were initially infected were still infected, and those that were initially uninfected remained free of TmRSV.

According to our data, there are different dandelion genotypes (dandelion is apomictic) in nature with varying responses to TmRSV, as exemplified by the interaction of seed source $\times$ virus (Table 1 ). There also was a significant interaction between mowing and TmRSV infection for flower production $(P=0.017)$ and fresh weight $(P=$ 0.0028 ), indicating that TmRSV affects dandelion plants that are mowed regularly more adversely than those not mowed. Seventythree percent of all plants survived (produced new growth) 2 years after planting, irrespective of mowing, seed source, or virus main effects. This experiment clearly shows that TmRSV reduced fresh weight and flower production of common dandelion and that the pathogenic effects probably vary with seed source.

\section{Literature Cited}

Mountain, W.L., C.A. Powell, L.B. Forer, and R.F. Stouffer. 1983. Transmission of tomato ringspot virus from dandelion via seed and dagger nematodes. Plant Dis. 67:867-868.

Powell, C.A., L.B. Forer, R.F. Stouffer, J.N. Cummins, D. Gonsalves, D.A. Rosenberger, J. Hoffman, and R.M. Lister. 1984a. Orchard weeds as hosts of tomato ringspot and tobacco ringspot viruses. Plant Dis. 68:242-244.

Powell, C.A., W.L. Mountain, T. Dick, L.B. Forer, M.A. Derr, L.D. Lathrop, and R.F. Stouffer. 1984b. Distribution of tomato ringspot virus in dandelion in Pennsylvania. Plant Dis. 68:796-798.
Table 1. Field vigor of dandelion as influenced by mowing, seed source, and tomato ringspot virus infection, as determined after 2 years of growth.

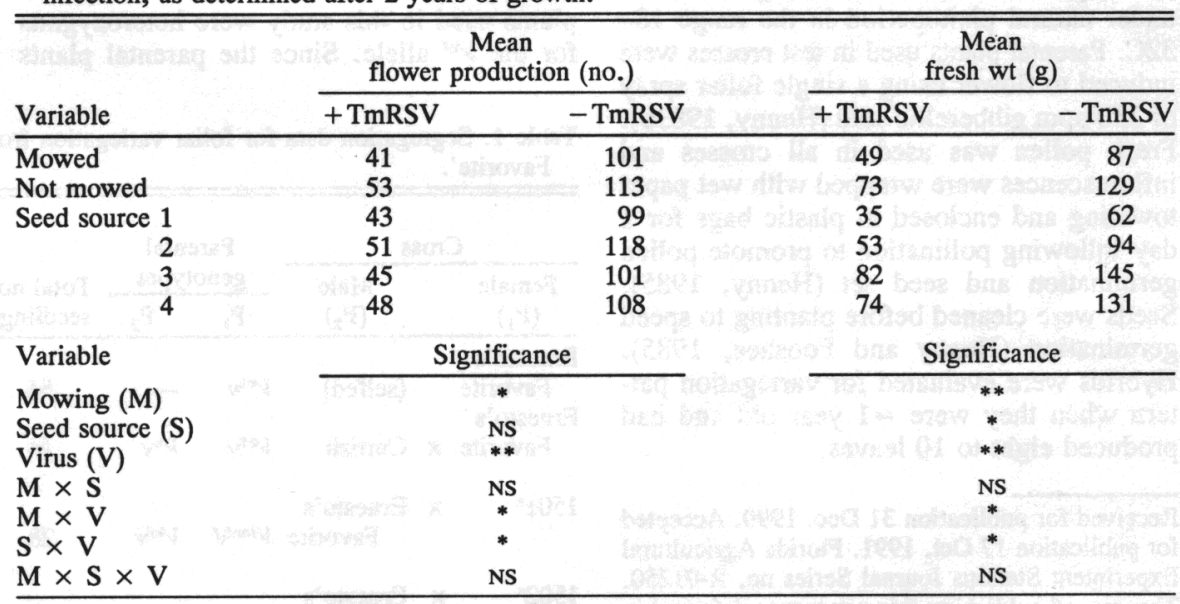

NS,*,**Nonsignificant or significant at $P=0.05$ or 0.01 , respectively. 